\title{
De-escalating Treatment for Ductal Carcinoma In Situ
}

\author{
Giacomo Montagna, Monica Morrow* \\ Breast Service, Department of Surgery, Memorial Sloan Kettering Cancer Center, New York, NY
}

*Corresponding author:

Monica Morrow, MD

Breast Service, Department of Surgery Memorial Sloan Kettering Cancer Center New York, NY

E-Mail: morrowm@mskcc.org

${ }^{*}$ ORCID No. 0000-0003-4636-8313
Received: 20.10 .2021 Accepted: 27.11.2021

\section{Rezumat}

Carcinomul ductal in situ (CDIS) reprezintă un tip de patologie mamară heterogenă. Pilonul principal în tratamentul CDIS este reprezentat de chirurgie, fie că este vorba de excizie locală largă însoțită de radioterapie (RT) adjuvantă sau mastectomie ca opțiuni standard. În scopul reducerii riscului de recidivă se poate lua în calcul şi terapia endocrină. Rata de supraviețuire pe termen lung este excelentă, depăşind $95 \%$ în situațiile în care tratamentul standard este aplicat. Actualmente, strategia de tratament se bazează pe caracteristicile anatomo-patologice. Instrumente de predicție bazate pe analiza genomică au fost dezvoltate, însă studiile privind impactul acestora asupra recomandărilor de RT sunt înca în desfăşurare. Luând în calcul ipotezele legate de tratarea excesivă a cazurilor de CDIS, cu entuziasm, s-a ridicat problema diminuării (de-escaladării) tratamentului locoregional. Este cunoscut faptul că radioterapia înjumătățeşte riscul de recidivă, dar nu are niciun impact asupra ratei de supraviețiire de aceea, pentru pacienții considerați a fi cu risc scăzut, radioterapia ar putea fi omisă. Supravegherea activă pentru cazurile de CDIS cu risc scăzut a fost evaluată în 4 studii prospective. Dar selectarea pacienților cu risc scăzut rămâne încă o problemă neelucidată în cadrul acestor studii, pentru că pe de o parte nu există o standardizare clară a pacienților cu risc scăzut şi pe de altă parte nici nu există un prag al ratei de recidiva acceptată. În plus, nu este clar nici dacă pacienții sunt disponibili să accepte multiple proceduri precum sunt biopsiile seriate, investigațiile imagistice în detrimentul unor proceduri chirurgicale cu riscuri mici. De asemenea, pentru astfel de situatii trebuie să se ia în calcul şi impactul psihologic asupra pacienților care ar putea trece prin anxietatea legată de o posibilă recidivă. Relevanța clinică şi siguranța pacienților pentru o astfel de abordare urmează a fi elucidate în studii viitoare. 
Cuvinte cheie: carcinom ductal in situ, de-escaladare, îngrijire bazată pe biomarkeri, omiterea intervenției chirurgicale

\begin{abstract}
Ductal carcinoma in situ (DCIS) is a heterogenous disease. The mainstay of its management is surgery, and lumpectomy with or without radiation therapy (RT) or mastectomy are standard options. Endocrine therapy may be given to maximize risk reduction. With standard treatment, the longterm breast cancer-specific survival is excellent and exceeds $95 \%$. Currently, management strategies are based on standard clinicopathological features. Genomic tools to predict local recurrence have been developed, and prospective studies to evaluate their impact on RT recommendations and outcomes are ongoing. Because of concerns regarding overtreatment of DCIS, there has been much enthusiasm for de-escalating locoregional therapy. RT halves the risk of local recurrence but does not affect survival, and its omission can be considered in low-risk groups. Active surveillance for lowrisk DCIS is being evaluated in 4 prospective trials. The concern regarding these trials is whether the selected "low-risk" cases are truly at low risk, and what threshold of recurrence is considered acceptable. Additionally, it is unclear whether patients will be willing to trade short outpatient procedures for more biopsies, more imaging, and possibly increased concern about recurrence. The clinical relevance and the safety of this approach are yet to be determined.
\end{abstract}

Key words: DCIS, de-escalation, biomarker-driven care, omission of surgery

\section{Introduction}

Ductal carcinoma in situ (DCIS) or Stage 0 breast cancer represents almost $20 \%$ of all diagnosed breast cancers $(1,2)$ in screened populations. Because accurate methods to identify which DCIS will progress to invasive cancer are currently lacking, at present, all types of DCIS mandate treatment. Treatment is primarily surgical and includes lumpectomy with or without radiation therapy (RT) and mastectomy; endocrine therapy may be used after either approach. Outcomes following surgical treatment are excellent, with 10- and 20-year cause-specific survival rates of $98.9 \%$ and $96.7 \%$, respectively (3). However, recurrence rates vary widely with different treatments, and half of the recurrences are invasive (4), with a risk of breast cancer death.

There is no such thing as "bad" DCIS, and the concept of risk stratification has primarily been used to identify patients suitable for treatment with lumpectomy without RT.
Currently, risk stratification is based on conventional clinical and histopathological features (5). Genomic tools to predict risk of local recurrence (LR) have been developed $(6,7)$; however, their clinical utility has been questioned $(8,9)$, and they have not been proven to be cost-effective (10).

The aim of DCIS treatment is to eradicate disease, prevent recurrence, and minimize sequelae. RT after breast conservation reduced the risk of ipsilateral breast events, both invasive and non-invasive, by at least $50 \%$, but does not improve survival (11-15). Given that, if left untreated, only $25 \%$ to $50 \%$ of cases will progress to invasive disease (16-19) and that some estrogen receptor (ER) positive DCIS may resolve with endocrine therapy alone $(20,21)$, many have raised concerns about overtreatment. The markedly increased detection rate of DCIS in screened populations, coupled with the lack of a corresponding reduction in invasive breast cancer incidence, supports the argument that not all 
DCIS is an obligate precursor of malignancy, and thus does not require treatment (22). In an effort toward an individualized approach, different de-escalation strategies in lowrisk patients have been proposed, including omission of RT, hypofractionation, and omission of surgery (15,23-27). However, several concerns exist regarding the safety of observation alone, even for a very select group of low-risk DCIS patients (28). In this review, we focus on the benefits of adjuvant treatment, the selection of low-risk DCIS for de-escalation of locoregional therapy, and the potential pitfalls of active surveillance.

\section{Outcomes of DCIS with Standard Treatment}

Much of the enthusiasm for de-escalating locoregional therapy for DCIS is derived from epidemiological studies showing very low breast cancer-specific mortality in patients treated with standard modalities. Narod et al., using the Surveillance, Epidemiology, and End Results (SEER) database, analyzed data from 108,196 patients with DCIS treated with conventional modalities (breast conservation with or without radiotherapy, and endocrine therapy or mastectomy) between 1988 and 2001. At 10 and 20 years follow-up, the breast cancer-specific mortality was $1.1 \%$ and $3.3 \%$, respectively, with no differences among treatment groups. The risk of dying of breast cancer among patients with DCIS was 1.8 times greater than that of the general population (standardized mortality ratio 1.8, 95\% confidence interval [CI] 1.7-1.9). The risk of death at 20 years was higher for young women (age $<35$ years) than for older women $(7.8 \%$ versus $3.2 \%, \mathrm{p}<0.001$ ), and for Black women compared to non-Hispanic White women $(7.0 \%$ versus $3.0 \%, p<0.001)$. Among patients who received a lumpectomy, RT reduced the risk of LR (2.5\% versus $4.9 \%$, adjusted hazard ratio [HR] $0.47,95 \%$ CI $0.42-0.53$ ), but not of breast cancer-specific mortality $(0.8 \%$ versus 0.9\%, HR 0.86, 95\% CI 0.67-1.10). Nonetheless, the risk of death was significantly increased in patients with LR compared with those without LR (HR 18.1, 95\% CI 14.0-23.6) (3).
Many have interpreted these results as evidence that DCIS should be considered a non-lethal disease and a risk factor for invasive cancer, rather than a true precursor (29), but this is not the case. Although our understanding of the natural history of DCIS is poor and, and although some forms of DCIS may be indolent, there is evidence that more than $50 \%$ of cases will progress to invasive cancer if left untreated (19). Additionally, half of the recurrences after breast conservation, with or without RT, are invasive even among patients under regular surveillance and those deemed to be "low risk" (11-15,28,30). Finally, if DCIS acted like other high-risk lesions, the risk of LR would not be affected by margin status. Instead, the risk of LR is doubled when margins are positive $(31,32)$.

\section{Benefit of Adjuvant Radiation and Endocrine Therapy Following Breast Conservation}

\section{Adjuvant Radiation}

Four prospective randomized trials (11-14) conducted in the 1980s and 1990s have evaluated the role of RT after breast conservation for DCIS. These trials, which included all subtypes of DCIS, have demonstrated that RT reduces, the risk of any (invasive and in situ) ipsilateral breast event by approximately $50 \%$ (Table 1). However, none of these trials showed a survival benefit. An individual patient-level meta-analysis of these trials performed by the Early Breast Cancer Trialists' Collaborative Group, which included 3729 women, demonstrated that RT is associated with an absolute $15.2 \%$ reduction in LR at 10 years $(12.9 \%$ with $\mathrm{RT}$ versus $28.1 \%$ without RT, $\mathrm{p}<0.00001)$. This benefit was present in all subgroups regardless of age, grade, tumor size, margin status, and use of tamoxifen (30). The proportional reduction in ipsilateral breast events was greater in older women than it was in younger (10-year absolute risk: $18.5 \%$ versus $29.1 \%$ in women age $<50$ years, and $10.8 \%$ versus $27.8 \%$ in women age $\geq 50$ years; $p<0.0004$ ), but did not differ significantly according to any other available factor. Importantly, RT reduced LR 
Table 1. Randomized controlled trials evaluating the benefit of RT after BCS for DCIS.

\begin{tabular}{|c|c|c|c|c|c|c|c|c|c|}
\hline Study & Design & Years & $\begin{array}{l}\text { Sample } \\
\text { size (n) }\end{array}$ & $\begin{array}{l}\text { Inclusion } \\
\text { criteria }\end{array}$ & RT dose & $\begin{array}{l}\text { Median } \\
\text { follow-up } \\
\text { (years) }\end{array}$ & $\begin{array}{l}\text { Rate of LR } \\
\text { without RT }\end{array}$ & $\begin{array}{l}\text { Rate of } \\
\text { LR with } \\
\text { RT }\end{array}$ & $\begin{array}{l}\text { Relative } \\
\text { risk } \\
\text { reduction }\end{array}$ \\
\hline NSABP B-17 12 & $\begin{array}{l}\text { Multicenter RCT, } \\
2 \text { arms, BCS } \pm \text { RT }\end{array}$ & $\begin{array}{l}1985- \\
1990\end{array}$ & 818 & $\begin{array}{l}\text { No age limit, } \\
\text { multifocal } \\
\text { disease allowed, } \\
\text { negative margins }\end{array}$ & $\begin{array}{l}50 \text { Gy in } 25 \\
\text { fractions } \\
\text { ( } 9 \% \text { received } \\
\text { a boost) }\end{array}$ & 17.3 & $35 \%$ & $18 \%$ & $50 \%$ \\
\hline EORTC $10853^{13}$ & $\begin{array}{l}\text { Multicenter RCT, } \\
2 \text { arms, BCS } \pm R T\end{array}$ & $\begin{array}{l}1986- \\
1996\end{array}$ & 1,010 & $\begin{array}{l}\text { Age }<70, \\
\text { Lesion }<5 \mathrm{~cm}, \\
\text { No Paget's disease }\end{array}$ & $\begin{array}{l}50 \text { Gy in } 25 \\
\text { fractions (5\% } \\
\text { received a boost) }\end{array}$ & 15.8 & $31 \%$ & $18 \%$ & $48 \%$ \\
\hline SweDCIS ${ }^{11}$ & $\begin{array}{l}\text { Multicenter RCT, } \\
2 \text { arms, BCS } \pm \text { RT }\end{array}$ & $\begin{array}{l}1987- \\
1999\end{array}$ & 1,046 & $\begin{array}{l}\text { Screening detected, } \\
\text { lesion occupying } \\
\text { less than a quadrant, } \\
\text { no Paget's disease" }\end{array}$ & $\begin{array}{l}50 \text { Gy in } 25 \\
\text { fractions or } 54 \text { Gy } \\
\text { in two series with } \\
\text { a gap of } 2 \text { weeks } \\
\text { (boost not } \\
\text { recommended) }\end{array}$ & 20 & $32 \%$ & $20 \%$ & $37.5 \%$ \\
\hline UK/ANZ DCIS ${ }^{14}$ & $\begin{array}{l}2 \times 2 \text { factorial design, } \\
\mathrm{BCS} \pm \mathrm{RT} \pm \\
\text { endocrine therapy }\end{array}$ & $\begin{array}{l}1990- \\
1998\end{array}$ & $475^{\star}$ & $\begin{array}{l}\text { No age limit, } \\
\text { no Paget's disease, } \\
\text { negative margins }\end{array}$ & $\begin{array}{l}50 \text { Gy in } 25 \text { fractions } \\
\text { (boost not } \\
\text { recommended) }\end{array}$ & 12.7 & $25 \%$ & $9 \%$ & $69 \%$ \\
\hline
\end{tabular}

RT, radiation therapy; BCS, breast-conserving surgery; DCIS, ductal carcinoma in situ; LR, local recurrence; NSABP, National Surgical Adjuvant Breast and Bowel Project; RCT, randomized controlled trial; EORTC, European Organisation for Research and Treatment of Cancer; SweDCIS, Swedish ductal carcinoma in situ; UK/ANZ, United Kingdom, Australia, and New Zealand

${ }^{+} 21 \%$ had close $(<1 \mathrm{~mm})$, involved, or unknown margin status

*Patients not receiving tamoxifen

${ }^{*}$ Negative margins were not mandatory: $9.9 \%$ in the BCS + RT arm and $11.5 \%$ in the BCS-alone arm had positive margins.

risk even for women at low risk, such as those with small, low-grade DCIS and negative margins $\left(18.0 \%\right.$ absolute reduction in the $10^{-}$ year risk of ipsilateral breast events $(12.1 \%$ versus $30.1 \%, \mathrm{p}=0.002)(30)$.

\section{Adjuvant Endocrine Therapy}

The use of adjuvant endocrine therapy for DCIS was investigated in 2 randomized trials, the United Kingdom, Australia, and New Zealand (UK/ANZ) DCIS trial and the National Surgical Adjuvant Breast and Bowel Project (NSABP) B-24 trial, both of which have demonstrated a relative risk reduction of approximately $25 \%(12,14)$. In the UK/ANZ DCIS trial, the benefit of tamoxifen was seen only in patients who did not receive RT. Among them, tamoxifen resulted in an absolute 10-year reduction in recurrent ipsilateral DCIS of $3 \%(p=0.04)$, but had no effect on ipsilateral invasive recurrence (14). In the NSABP-B24 trial, in which all patients received $\mathrm{RT}$, tamoxifen reduced the absolute 10-year risk of invasive recurrence by $2.4 \%$ but did not reduce the risk of ipsilateral DCIS recurrence (12). In both trials, the addition of tamoxifen also resulted in a reduction in contralateral breast cancer (54\% in UK/ANZ
DCIS, 32\% in NSABP B-24), but was not associated with a reduction in breast cancerspecific or overall mortality in either trial $(12,14)$. The hormone receptor status of patients enrolled in both trials was not known at the time of enrollment. Allred et al. performed a retrospective analysis of 732 cases from NSABP B-24 and found, as expected, that the benefit of tamoxifen was limited to patients with ER positive DCIS. In these patients, tamoxifen reduced risk of any breast cancer event (HR 0.58, 95\% CI 0.42-0.81), any invasive breast cancer (HR 0.53, 95\% CI 0.340.82 ), and any contralateral breast cancer (HR 0.50, 95\% CI 0.28-0.88) (33). Finally, 2 randomized trials compared tamoxifen with anastrozole for DCIS in postmenopausal women. In the NSABP B-35 trial, in which all patients received $\mathrm{RT}$, the 10-year breast cancer-free interval was higher among women who received anastrozole compared with those who received tamoxifen (93.1\% versus $89.1 \%$, HR 0.73 , 95\% CI 0.56-0.96) (34). In the International Breast Cancer Intervention Study (IBIS)-II trial, in which only $71 \%$ of patients received RT, there was no difference in LR at a median follow-up of 7.2 years between the 2 groups (overall recurrence rate: 
$5 \%$ in both groups) (35). The combination of the relatively small absolute benefit of endocrine therapy in reducing the risk of LR, and the side effect profiles of tamoxifen and the aromatase inhibitors has resulted in relatively low patient uptake of these agents in DCIS (36-40).

Although both RT and endocrine therapy decrease LR, they do not improve survival, and they are associated with potentially severe side effects.41-43 Ideally, their use should be selective and limited to patients at higher risk of LR who are likely to derive greater benefit. A major goal of clinical research for the last 2 decades has been to identify patients at sufficiently low risk of LR who would be candidates for treatment de-escalation.

\section{Can We Select Low-Risk DCIS Using Conventional or Genomic Tools?}

\section{Clinical and Pathological Features to Define Low-Risk DCIS}

Several studies have evaluated different methods to predict the risk of recurrence. The
Memorial Sloan Kettering Cancer Center (MSKCC) DCIS Nomogram includes 10 clinicopathological factors (including age, family history, year of surgery, clinical versus radiologic presentation, nuclear grade, necrosis, margins, and number of re-excisions) and estimates the risk of LR and invasive recurrence at 5 and 10 years after breastconserving surgery (BCS) (5). The model has been internally validated and demonstrates good discrimination (C-index 0.704; bootstrap corrected 0.688), and external validation with independent populations has been demonstrated in several retrospective studies (44-47). The nomogram is available online (at www.nomograms.org) free of charge.

The most important factors for risk stratification are age, tumor size, nuclear grade and margin status (48). Three prospective studies (15,49-51) have evaluated whether low-risk DCIS can be defined using these features (Table 2). In aggregate, these studies showed that even among carefully selected DCIS patients (with low/intermediate-grade tumors measuring less than $2.5 \mathrm{~cm}$ in size, and with final margins of at least $3 \mathrm{~mm}$ or a negative

Table 2. Studies identifying low-risk DCIS based on clinicopathological features

\begin{tabular}{|c|c|c|c|c|c|c|c|c|}
\hline Study & Design & Years & $\begin{array}{c}\text { Sample size } \\
\text { (n) }\end{array}$ & Inclusion criteria & $\begin{array}{c}\text { Endocrine } \\
\text { therapy }\end{array}$ & $\begin{array}{c}\text { Median } \\
\text { follow-up } \\
\text { (years) }\end{array}$ & $\begin{array}{l}\text { Rate of LR } \\
\text { without RT }\end{array}$ & $\begin{array}{c}\text { Rate of LR } \\
\text { with RT }\end{array}$ \\
\hline $\begin{array}{l}\text { Dana-Farber Cancer } \\
\text { Institute/Brigham and } \\
\text { Women's Hospital and } \\
\text { Harvard Medical School }{ }^{49}\end{array}$ & $\begin{array}{l}\text { Single-arm } \\
\text { prospective } \\
\text { study }\end{array}$ & 1995-2002 & $143^{+}$ & $\begin{array}{l}\text { Nuclear Grade I and II, } \\
\leq 2.5 \mathrm{~cm} \text {, } \\
\text { margins } \geq 10 \mathrm{~mm} \text { or } \\
\text { neg. re-excision }\end{array}$ & Not allowed & 11 & $\begin{array}{c}13 \% \\
\text { (at } 10 \text { years) }\end{array}$ & NA \\
\hline ECOG-ACRIN E5194 50 & $\begin{array}{l}\text { Prospective } \\
\text { non-randomized } \\
\text { trial ( } 2 \text { cohorts) }\end{array}$ & $1997-2002$ & $\begin{array}{l}\text { Cohort 1: } 561 \\
\text { Cohort 2: } 104\end{array}$ & $\begin{array}{l}\text { Cohort 1: Nuclear } \\
\text { Grade I and II, } \leq 2.5 \mathrm{~cm} \text {, } \\
\text { margins } \geq 3 \mathrm{~mm} \text { or neg. } \\
\text { re-excision } \\
\text { Cohort } 2 \text { : Nuclear Grade III, } \\
\leq 1 \mathrm{~cm} \text {, margins } \geq 3 \mathrm{~mm} \\
\text { or neg. re-excision }\end{array}$ & $\begin{array}{l}\text { Initially not } \\
\text { allowed* } \\
\text { (30\% received } \\
\text { tamoxifen) }\end{array}$ & 12 & $\begin{array}{l}\text { Cohort } 1: 14.4 \% \\
\text { (at } 12 \text { years) } \\
\text { Cohort } 2: 24.6 \% \\
\text { (at } 12 \text { years) }\end{array}$ & $\%$ \\
\hline NRG/RTOG $9804^{15}$ & $\begin{array}{l}\text { Multicenter RCT, } \\
2 \text { arms, } \mathrm{RT}^{\#} \\
\text { versus no RT }\end{array}$ & $1998-2006$ & 636 & $\begin{array}{l}\text { Nuclear Grade I and II, } \\
\leq 2.5 \mathrm{~cm} \text {, margins } \geq 3 \mathrm{~mm}\end{array}$ & $\begin{array}{l}\text { Initially } \\
\text { mandatory } \\
\text { (62\% received } \\
\text { tamoxifen) }\end{array}$ & 12 & $\begin{array}{c}11.4 \% \\
\text { (at } 12 \text { years) }\end{array}$ & $\begin{array}{c}2.8 \% \\
\text { (at } 12 \text { years) }\end{array}$ \\
\hline
\end{tabular}

DCIS, ductal carcinoma in situ; RT, radiation therapy; NA, not applicable; LR, local recurrence; ECOG-ACRIN, Eastern Cooperative Oncology Group-American College of Radiology Imaging Network; NRG/RTOG, NRG Oncology/Radiation Therapy Oncology Group.

${ }^{\dagger} 158$ patients were enrolled in the study

"In May 2000 the study was amended to allow treatment with adjuvant tamoxifen in an optional, non-randomized fashion

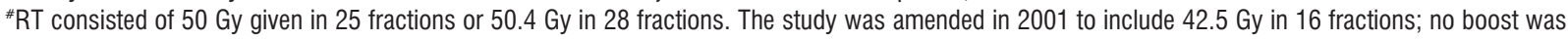
allowed in the study

${ }^{\# \#}$ In 2001 the study was amended to make tamoxifen optional. 
re-excision), omission of RT resulted in LR in more than $10 \%$ of cases (approximately $1.5 \%$ per year).

\section{Molecular Signatures to Define Low-Risk DCIS}

Recent efforts to refine DCIS risk stratification have focused on genomic profiling. The Oncotype DX DCIS score (Exact Sciences, Redwood City, CA) is a 12-gene assay that was developed to estimate the 10-year risk of LR after lumpectomy without RT $(6,52)$. It consists of 7 tumor genes and 5 reference genes. The first validation was performed using a subset of 327 patients from the Eastern Cooperative Oncology GroupAmerican College of Radiology Imaging Network (ECOG-ACRIN) E5194 study. In it, Solin et al. found that the Oncotype DX DCIS score was significantly associated with developing any LR (HR 2.31, 95\% CI 1.154.49) including invasive recurrence (HR 3.68, 95\% CI 1.34-9.62) (6). However, the Oncotype DX DCIS score did not predict the benefit of RT (53). Rakovitch et al. further validated the Oncotype DX DCIS score in a populationbased cohort of 571 patients from Ontario. On multivariable analysis, a 50-point increase in the Oncotype DX DCIS score was significantly associated with LR (HR 1.68, 95\% CI 1.082.62); nonetheless, other clinicopathological factors (including age at diagnosis, multifocality, and tumor size) had a larger effect than the Oncotype DX DCIS score (52). In a joint analysis of these 2 cohorts, Rakovitch et al. combined the Oncotype DX DCIS score with multiple clinicopathological features (i.e., age, tumor size and year of diagnosis) and identified a group of women with a 10-year risk of recurrence $<10 \%$. Patients 50 years of age or older with a tumor size $\leq 1 \mathrm{~cm}$ and a low-risk Oncotype DX DCIS score, treated with lumpectomy alone, had an average 10-year LR risk of 7.2\% (54).

Interestingly, VanZee et al. compared the risk estimates from the MSKCC DCIS nomogram and the refined Oncotype DX DCIS score, and found remarkable agreement in patients with margins wider than $2 \mathrm{~mm}$, but not in those with close margins $(\leq 2 \mathrm{~mm})$, where the refined Oncotype DX DCIS score appeared to underestimate risk. They concluded that the cost of the refined Oncotype DX DCIS score does not seem to be justified (8). Similarly, Radlow et al. investigated the cost effectiveness of the Oncotype DX DCIS score using a Markov model and found that none of the simulated strategies incorporating the Oncotype DX DCIS score were cost effective (10).

More recently, a molecular signature which combines several biomarkers with clinico-pathologic factors, called DCISionRT (PreludeDX), was shown to be predictive of LR risk and to predict benefit from RT (7). In a group of 216 patients treated with lumpectomy alone, those with a low DCISionRT score had a 10-year absolute risk of any ipsilateral breast event of $8 \%$ (95\% CI 0-14). Interestingly, an interaction analysis demonstrated that patients with elevated DCISionRT scores had a statistically greater benefit from RT than those with low DCISionRT scores $(7,55)$.

Taken together, these results suggest that the combination of clinicopathologic factors and molecular signatures is better at identifying women with low-risk DCIS than either alone. Currently, 3 prospective studies are evaluating how these 2 molecular-based approaches affect $\mathrm{RT}$ recommendations and outcomes $(56,57)$.

\section{De-escalating Treatment - Hypofractionation, No Radiation, No Surgery}

\section{De-escalation of $R T$}

Hypofractionated RT in early-stage breast cancer has been shown to be as effective as conventional fractionation, with similar control rates and cosmetic outcomes (58-61). The Danish Breast Cancer Group (DBCG) HYPO Trial was a randomized phase III trial of hypofractionation versus standard fractionated RT in patients with early-stage breast cancer and DCIS. Of the 1854 patients enrolled, 246 were high-risk DCIS (defined as DCIS requiring $\mathrm{RT}$ ). The 9-year risk of locoregional recurrence in the DCIS group was $4.9 \%$ in the 50Gy 
control arm and $6.5 \%$ in the experimental arm (HR 1.40, 95\% CI 0.49-4.05). Additionally, rates of breast induration were similar between the 2 groups (23). The Breast International Group (BIG) 3-07/Trans Tasman Radiation Oncology Group (TROG) 07.01 is a large 4-arm randomized trial which is evaluating hypofractionation versus conventional fractionation with or without boost in patients with high-risk DCIS after breast conservation (62). If proven to be non-inferior, hypofractionation with or without boost may become an alternative $\mathrm{RT}$ regimen for all types of DCIS.

For patients with low-risk DCIS, omission of $\mathrm{RT}$ remains an option as long as risks and benefits are discussed, and as long as the patient is comfortable with the decision. For those who decide to undergo RT, studies have shown that accelerated partial-breast irradiation achieves similar local control as wholebreast RT (63), and this approach is supported by the current National Comprehensive Cancer Network guidelines (64).

\section{Omission of Surgery for Low-Risk DCIS}

The rationale behind elimination of surgery for low-risk DCIS is that in very small, retrospective studies of patients initially diagnosed with benign disease who were found to have DCIS on subsequent histologic review, only about half progressed to invasive cancer over a period of 30 years $(16,17,19,65,66)$. In a recent analysis from the SEER database of 1286 women diagnosed with DCIS between 19922014 who did not undergo locoregional therapy, the 10-year risk of ipsilateral invasive breast cancer was $12.2 \%$ (95\% CI 8.6-17.1) among patients with low- and intermediate-grade DCIS as compared to $17.6 \%$ (95\% CI 12.1-25.2) among patients with high-grade DCIS (18). Additionally, autopsy studies have shown that among women who died of causes other than breast cancer, $7-39 \%$ had undetected DCIS, suggesting that for some women, DCIS remains indolent and will never develop into a clinically significant disease (67). Finally, recent data suggest that some ER positive DCIS may resolve with endocrine therapy alone. The Cancer and Leukemia Group B (CALGB) 40903 study was a phase II singlearm study of preoperative letrozole for ER positive DCIS in postmenopausal women. After 6 months of treatment, all patients underwent surgery. In that study, $15 \%$ of patients had no residual disease found at time of surgery (25).

Based on these observations, 4 prospective studies of active surveillance for low-risk DCIS are being conducted worldwide: LORIS [Surgery Versus Active Monitoring for LowRisk DCIS] in the United Kingdom, LORD [Low Risk DCIS] in the Netherlands, COMET [Comparing an Operation to Monitoring, With or Without Endocrine Therapy] in the United States, and LORETTA [Low-Risk DCIS with Endocrine Therapy Alone-Tamoxifen] in Japan (Table 3) $(24-27,68)$. The first 3 studies are randomized controlled trials comparing guideline concordant care with observation alone \pm endocrine therapy, while the LORETTA study is a prospective, single-arm trial of active surveillance and endocrine therapy. The primary endpoint of these studies is either time to progression to invasive cancer or $2-, 5$, and 10-year rate of invasive progression. Recently, the LORD trial has been converted to a non-randomized patient preference trial due to poor accrual.

While these studies will provide valuable information on the natural history of DCIS, they raise multiple clinical questions. What is the upgrade rate of patients who are eligible for these trials? What proportion of all DCIS patients will benefit from the results of these studies? And, more importantly, what impact will this approach have on survival from DCIS?

It is well known that in patients diagnosed as having DCIS with core needle biopsy, invasive cancer may be found with surgical excision. Pilewskie et al. examined the upgrade rate of LORIS-eligible patients and found that 58/296 (20\%) of cases had invasive carcinoma in the surgical specimen. Of the cases with invasive cancer, $31 \%$ were $\mathrm{p} \mathrm{T} 1 \mathrm{~b}$ or larger and 5\% were $\mathrm{pN} 1$ (28). Other studies in the same DCIS population have reported upgrade rates ranging between 7-24\% (69-71). 
Table 3. Ongoing Active Surveillance Trials for Low-Risk DCIS

\begin{tabular}{|c|c|c|c|c|c|c|c|c|c|}
\hline Study & Country & Design & $\begin{array}{l}\text { Year of } \\
\text { activation }\end{array}$ & $\begin{array}{l}\text { Sample } \\
\text { size (n) }\end{array}$ & $\begin{array}{l}\text { Age } \\
\text { (years) }\end{array}$ & Inclusion criteria & $\begin{array}{l}\text { Surveillance } \\
\text { schedule }\end{array}$ & $\begin{array}{l}\text { Endocrine } \\
\text { therapy }\end{array}$ & $\begin{array}{l}\text { Primary } \\
\text { endpoint }\end{array}$ \\
\hline $\mathrm{LORIS}^{27}$ & $\begin{array}{l}\text { United } \\
\text { Kingdom }\end{array}$ & $\begin{array}{l}\text { Multicenter } \\
\text { RCT, } 2 \text { arms, } \\
\text { surveillance } \\
\text { versus standard } \\
\text { local treatment }\end{array}$ & 2014 & 932 & $\geq 48$ & $\begin{array}{l}\text { Screen detected, } \\
\text { Grade I or II, no } \\
\text { comedo necrosis, } \\
\text { any receptor status, } \\
\text { any size allowed }\end{array}$ & $\begin{array}{l}\text { Bilateral MMG } \\
\text { every } 12 \text { months }\end{array}$ & Allowed & $\begin{array}{l}\text { 5-year ipsilateral } \\
\text { invasive breast } \\
\text { cancer-free } \\
\text { survival }\end{array}$ \\
\hline $\mathrm{LORD}^{24}$ & Europe & $\begin{array}{l}\text { Multicenter RCT, } \\
2 \text { arms, } \\
\text { surveillance versus } \\
\text { standard local } \\
\text { treatment" }\end{array}$ & 2017 & 1240 & $\geq 45$ & $\begin{array}{l}\text { Screen detected, } \\
\text { Grade I, no comedo } \\
\text { necrosis, any receptor } \\
\text { status, any size } \\
\text { allowed }\end{array}$ & $\begin{array}{l}\text { Bilateral MMG } \\
\text { every } 12 \text { months }\end{array}$ & $\begin{array}{l}\text { Not } \\
\text { allowed }\end{array}$ & $\begin{array}{l}\text { 10-year ipsilateral } \\
\text { invasive breast } \\
\text { cancer-free } \\
\text { survival }\end{array}$ \\
\hline $\mathrm{COMET}^{25}$ & $\begin{array}{l}\text { United } \\
\text { States }\end{array}$ & $\begin{array}{l}\text { Multicenter RCT, } \\
2 \text { arms, surveillance } \\
\text { versus standard } \\
\text { local treatment }\end{array}$ & 2017 & 1200 & $\geq 40$ & $\begin{array}{l}\text { Screen detected, } \\
\text { Grade I or II, comedo } \\
\text { necrosis allowed, } \\
\text { HR+ only, any size } \\
\text { allowed ( } 2 \text { biopsies } \\
\text { required if }>4 \mathrm{~cm} \text { ) }\end{array}$ & $\begin{array}{l}\text { Ipsilateral MMG } \\
\text { every } 6 \text { months, } \\
\text { contralateral } \\
\text { MMG every } 12 \\
\text { months }\end{array}$ & Allowed & $\begin{array}{l}\text { 2-year and 5-year } \\
\text { ipsilateral invasive } \\
\text { breast cancer-free } \\
\text { survival }\end{array}$ \\
\hline LORETTA $^{26,68}$ & Japan & Single-arm registry & 2017 & 340 & $\geq 40$ & $\begin{array}{l}\text { Screen detected, } \\
\text { Grade I or II, no } \\
\text { comedo necrosis, } \\
\mathrm{HR}+\text { only, }<2.5 \mathrm{~cm}\end{array}$ & $\begin{array}{l}\text { Ipsilateral MMG/US } \\
\text { every } 6 \text { months, } \\
\text { contralateral MMG/ } \\
\text { US every } 12 \text { months }\end{array}$ & Mandatory & $\begin{array}{l}\text { 5-year ipsilateral } \\
\text { invasive breast } \\
\text { cancer-free } \\
\text { survival }\end{array}$ \\
\hline
\end{tabular}

DCIS, ductal carcinoma in situ; LORIS, Surgery Versus Active Monitoring for Low-Risk DCIS; RCT, randomized controlled trial; MMG, mammogram; LORD, Low Risk DCIS; COMET, Comparing an Operation to Monitoring, With or Without Endocrine Therapy; HR+, hormone receptor positive; LORETTA, Low-Risk DCIS with Endocrine Therapy Alone-Tamoxifen; US, ultrasound.

\#The LORD trial was converted to a non-randomized patient preference trial in August 2020.

This suggests that even low-risk DCIS is associated with a substantial upgrade rate to invasive carcinoma.

Pilewskie et al. also analyzed DCIS patients treated with breast conservation at MSKCC between January 1996 and January 2011. Of 2394 cases analyzed, only 401 (16.7\%) met the LORIS inclusion criteria, suggesting that only a small minority of patients will benefit from the results of these studies (62).

Finally, the potential impact of a surveillance strategy on overall mortality from DCIS remains to be determined. A combined analysis of the NSABP B-17 and B-24 trials showed that women who developed an invasive ipsilateral recurrence after treatment for DCIS were at increased risk of dying of breast cancer (HR 7.06, 95\% CI 4.14-12.03) (12). Available studies demonstrate that even among patients with small low-risk DCIS which was completely excised, the risk of developing subsequent breast events is significant (Table 2), and this is also true among those meeting the criteria for trials of active surveillance. In the study from Pilewskie et al., 193 of 401 patients were treated with lumpectomy alone. In that group, the 10-year rate of any LR after lumpectomy alone was $12 \%$, with a $6 \%$ risk of invasive recurrence (27). In another study from MSKCC of women with minimal-volume DCIS which was completely excised at the time of core biopsy, the rate of ipsilateral breast events in those who did not receive RT was $14.5 \%$ at 10 years (72). Given that women managed with observation are expected to develop higher rates of invasive cancers than those undergoing excision with or without RT, this approach may result in an increased mortality risk.

\section{The Patient Perspective}

Despite excellent oncological prognosis, women diagnosed with DCIS experience substantial psychological distress, and many overestimate their risk of local and distant recurrence (73). In a longitudinal study of women diagnosed with DCIS, Partridge et al. reported that $39 \%$ of them perceived at least a moderate risk for invasive cancer in the next 5 
years, $53 \%$ perceived at least a moderate risk for invasive cancer in their lifetime; and $28 \%$ perceived at least a moderate likelihood of DCIS spreading to other places in their body (74). In a follow-up study of this cohort, 5 years after completing treatment, a substantial proportion of women continued to overestimate their risk of developing breast cancer in the future (75). Katz et al. surveyed 659 women after receipt of surgery for DCIS and found that recurrence risk concern was a strong predictor of receipt of mastectomy. In that study, only $13.1 \%$ of patients who were not influenced or were slightly influenced by concerns about recurrence received mastectomy, compared with $48.8 \%$ of women who were greatly influenced by this concern (76).

The concern of investing many resources in trials of observation for DCIS is that not only will these studies alter the management of a small minority of DCIS patients, but also that women may not be willing to trade a 1 -hour lumpectomy for more biopsies, more imaging, and, possibly, more concern about developing invasive cancer in the future (77). Over the past few decades in the United States, there has been a fourfold increase in the rate of contralateral prophylactic mastectomy for DCIS, demonstrating a desire for achieving peace of mind despite a lack of survival benefit $(78,79)$. Similarly, patients are willing to undergo RT to reduce the risk of LR, particularly invasive recurrence, even though RT for DCIS does not affect mortality. For some patients, LR is a devastating event with great impact on quality of life, which many women may not be willing to experience to avoid a small surgery.

\section{Conclusions}

With standard treatment, the long-term outcome of DCIS is excellent. Randomized controlled trials have shown that adding RT and endocrine therapy after BCS reduces the risk of LR, although neither treatment modality affects mortality. Clinicopathological features can be used to stratify risk and tailor adjuvant therapy. However, studies have shown that even among those with low-risk features when RT is omitted, the risk of LR is substantial (approximately $1.5 \%$ per year). The safety of managing DCIS non-operatively is uncertain, and clear evidence of a patient movement supporting this approach is lacking. De-escalation of locoregional treatment for DCIS to avoid overtreatment is reasonable; however, oncological safety should not be compromised, and the patient perspective should be taken into account.

\section{Disclosures}

Dr. Monica Morrow discloses receipt of honoraria from Exact Sciences and Roche. Dr. Giacomo Montagna has no conflict of interest disclosures to report. The authors report no prior presentation, and the findings presented in this manuscript have not been published elsewhere.

\section{References}

1. DeSantis CE, Ma J, Gaudet MM, Newman LA, Miller KD, Goding Sauer A, et al. Breast cancer statistics, 2019. CA Cancer J Clin. 2019;69(6):438-451.

2. Ernster VL, Ballard-Barbash R, Barlow WE, Zheng Y, Weaver DL, Cutter G, et al. Detection of ductal carcinoma in situ in women undergoing screening mammography. J Natl Cancer Inst. 2002;94(20):1546-54.

3. Narod SA, Iqbal J, Giannakeas V, Sopik V, Sun P. Breast Cancer Mortality After a Diagnosis of Ductal Carcinoma In Situ. JAMA Oncol. 2015;1(7): 888-896.

4. Silverstein MJ, Lagios MD, Martino S, Lewinsky BS, Craig PH, Beron PJ, et al. Outcome after invasive local recurrence in patients with ductal carcinoma in situ of the breast. J Clin Oncol. 1998;16(4):1367-73.

5. Rudloff U, Jacks LM, Goldberg JI, Wynveen CA, Brogi E, Patil S, et al. Nomogram for predicting the risk of local recurrence after breastconserving surgery for ductal carcinoma in situ. J Clin Oncol. 2010;28(23): 3762-9.

6. Solin LJ, Gray R, Baehner FL, Butler SM, Hughes LL, Yoshizawa C, et al. A multigene expression assay to predict local recurrence risk for ductal carcinoma in situ of the breast. J Natl Cancer Inst. 2013;105(10):701-10.

7. Bremer T, Whitworth PW, Patel R, Savala J, Barry T, Lyle S, et al. A Biological Signature for Breast Ductal Carcinoma In Situ to Predict Radiotherapy Benefit and Assess Recurrence Risk. Clin Cancer Res. 2018;24(23): 5895-5901.

8. Van Zee KJ, Zabor EC, Di Donato R, Harmon B, Fox J, Morrow M, et al. Comparison of Local Recurrence Risk Estimates After Breast-Conserving Surgery for DCIS: DCIS Nomogram Versus Refined Oncotype DX Breast DCIS Score. Ann Surg Oncol. 2019;26(10):3282-3288.

9. Van Zee KJ. ASO Author Reflections: Does Genomic Testing of DCIS Provide Added Value? And Is It Worth the Cost? Ann Surg Oncol. 2019;26(Suppl 3):702-703.

10. Raldow AC, Sher D, Chen AB, Recht A, Punglia RS. Cost Effectiveness of the Oncotype DX DCIS Score for Guiding Treatment of Patients With Ductal Carcinoma In Situ. J Clin Oncol. 2016;34(33):3963-3968.

11. Warnberg F, Garmo H, Emdin S, Hedberg V, Adwall L, Sandelin K, et al. Effect of radiotherapy after breast-conserving surgery for ductal carcinoma 
in situ: 20 years follow-up in the randomized SweDCIS Trial. J Clin Oncol. 2014;32(32):3613-8.

12. Wapnir IL, Dignam JJ, Fisher B, Mamounas EP, Anderson SJ, Julian TB, et al. Long-term outcomes of invasive ipsilateral breast tumor recurrences after lumpectomy in NSABP B-17 and B-24 randomized clinical trials for DCIS. J Natl Cancer Inst. 2011;103(6):478-88.

13. Donker M, Litiere S, Werutsky G, Julien JP, Fentiman IS, Agresti R, et al. Breast-conserving treatment with or without radiotherapy in ductal carcinoma In Situ: 15-year recurrence rates and outcome after a recurrence, from the EORTC 10853 randomized phase III trial. J Clin Oncol. 2013; 31(32):4054-9.

14. Cuzick J, Sestak I, Pinder SE, Ellis I0, Forsyth S, Bundred NJ, et al. Effect of tamoxifen and radiotherapy in women with locally excised ductal carcinoma in situ: Iong-term results from the UK/ANZ DCIS trial. Lancet Oncol. 2011;12(1):21-29.

15. McCormick B, Winter K, Hudis C, Kuerer HM, Rakovitch E, Smith BL, et al. RTOG 9804: a prospective randomized trial for good-risk ductal carcinoma in situ comparing radiotherapy with observation. J Clin Oncol. 2015; 33(7):709-15.

16. Collins LC, Tamimi RM, Baer HJ, Connolly JL, Colditz GA, Schnitt SJ. Outcome of patients with ductal carcinoma in situ untreated after diagnostic biopsy: results from the Nurses' Health Study. Cancer. 2005;103(9):17781784.

17. Sanders ME, Schuyler PA, Dupont WD, Page DL. The natural history of low-grade ductal carcinoma in situ of the breast in women treated by biopsy only revealed over 30 years of long-term follow-up. Cancer. 2005;103(12):2481-2484.

18. Ryser MD, Weaver DL, Zhao F, Worni M, Grimm LJ, Gulati R, et al. Cancer Outcomes in DCIS Patients Without Locoregional Treatment. J Natl Cancer Inst. 2019;111(9):952-960.

19. Sanders ME, Schuyler PA, Simpson JF, Page DL, Dupont WD. Continued observation of the natural history of low-grade ductal carcinoma in situ reaffirms proclivity for local recurrence even after more than 30 years of follow-up. Mod Pathol. 2015;28(5):662-669.

20. Hwang ES, Hyslop T, Hendrix LH, Duong S, Bedrosian I, Price E, et al. Phase II Single-Arm Study of Preoperative Letrozole for Estrogen ReceptorPositive Postmenopausal Ductal Carcinoma In Situ: CALGB 40903 (Alliance). J Clin Oncol. 2020; 38(12):1284-1292.

21. Gourd E. Preoperative endocrine therapy for ductal carcinoma in situ. Lancet Oncol. 2020;21(4):e184.

22. Bleyer A, Welch HG. Effect of three decades of screening mammography on breast-cancer incidence. N Engl J Med. 2012;367(21):1998-2005.

23. Offersen BV, Alsner J, Nielsen HM, Jakobsen EH, Nielsen MH, Krause M, et al. Hypofractionated Versus Standard Fractionated Radiotherapy in Patients With Early Breast Cancer or Ductal Carcinoma In Situ in a Randomized Phase III Trial: The DBCG HYPO Trial. J Clin Oncol. 2020;38(31): 3615-3625.

24. Elshof LE, Tryfonidis K, Slaets L, van Leeuwen-Stok AE, Skinner VP, Dif N, et al. Feasibility of a prospective, randomised, open-label, international multicentre, phase III, non-inferiority trial to assess the safety of active surveillance for low risk ductal carcinoma in situ - The LORD study. Eur J Cancer. 2015;51(12):1497-1510.

25. Hwang ES, Hyslop T, Lynch T, Frank E, Pinto D, Basila D, et al. The COMET (Comparison of Operative versus Monitoring and Endocrine Therapy) trial: a phase III randomised controlled clinical trial for low-risk ductal carcinoma in situ (DCIS). BMJ Open. 2019;9(3):e026797.

26. Kanbayashi $\mathrm{C}$, Iwata $\mathrm{H}$. Current approach and future perspective for ductal carcinoma in situ of the breast. Jpn J Clin Oncol. 2017:47(8):671-677.

27. Francis A, Thomas J, Fallowfield L, Wallis M, Bartlett JMS, Brookes C, et al. Addressing overtreatment of screen detected DCIS; the LORIS trial. Eur J Cancer. 2015;51(16):2296-303.

28. Pilewskie M, Olcese C, Patil S, Van Zee KJ. Women with Low-Risk DCIS Eligible for the LORIS Trial After Complete Surgical Excision: How Low Is Their Risk After Standard Therapy? Ann Surg Oncol. 2016;23(13):42534261.

29. Esserman L, Yau C. Rethinking the Standard for Ductal Carcinoma In Situ Treatment. JAMA Oncol. 2015;1(7):881-883.
30. Early Breast Cancer Trialists' Collaborative G, Correa C, McGale P, et al. Overview of the randomized trials of radiotherapy in ductal carcinoma in situ of the breast. J Natl Cancer Inst Monogr. 2010;2010(41):162-177.

31. Marinovich ML, Azizi L, Macaskill P, Irwig L, Morrow M, Solin LJ, et al. The Association of Surgical Margins and Local Recurrence in Women with Ductal Carcinoma In Situ Treated with Breast-Conserving Therapy: A MetaAnalysis. Ann Surg Oncol. 2016;23(12):3811-3821.

32. Van Zee KJ, Subhedar P, Olcese C, Patil S, Morrow M. Relationship Between Margin Width and Recurrence of Ductal Carcinoma In Situ: Analysis of 2996 Women Treated With Breast-conserving Surgery for 30 Years. Ann Surg. 2015;262(4):623-631.

33. Allred DC, Anderson SJ, Paik S, Wickerham DL, Nagtegaal ID, Swain SM, et al. Adjuvant tamoxifen reduces subsequent breast cancer in women with estrogen receptor-positive ductal carcinoma in situ: a study based on NSABP protocol B-24. J Clin Oncol. 2012;30(12):1268-73.

34. Margolese RG, Cecchini RS, Julian TB, Ganz PA, Costantino JP, Vallow LA, et al. Anastrozole versus tamoxifen in postmenopausal women with ductal carcinoma in situ undergoing lumpectomy plus radiotherapy (NSABP B-35): a randomised, double-blind, phase 3 clinical trial. Lancet. 2016; 387(10021):849-56.

35. Forbes JF, Sestak I, Howell A, Bonanni B, Bundred N, Levy C, et al. Anastrozole versus tamoxifen for the prevention of locoregional and contralateral breast cancer in postmenopausal women with locally excised ductal carcinoma in situ (IBIS-II DCIS): a double-blind, randomised controlled trial. Lancet. 2016:387(10021):866-73.

36. Land SR, Walcott FL, Liu Q, Wickerham DL, Costantino JP, Ganz PA. Symptoms and QOL as Predictors of Chemoprevention Adherence in NRG Oncology/NSABP Trial P-1. J Natl Cancer Inst. 2016;108(4).

37. Noonan S, Pasa A, Fontana V, Caviglia S, Bonanni B, Costa A, et al. A Survey among Breast Cancer Specialists on the Low Uptake of Therapeutic Prevention with Tamoxifen or Raloxifene. Cancer Prev Res (Phila). 2018; 11(1):38-43.

38. Omling S, Houssami N, McGeechan K, Zackrisson S, Jacklyn G, Walters D, et al. The management of women with ductal carcinoma in situ of the breast in Australia and New Zealand between 2007 and 2016. ANZ J Surg. 2021; 91(9):1784-1791. Epub 2021 Jun 1.

39. Flanagan MR, Rendi MH, Gadi VK, Calhoun KE, Gow KW, Javid SH. Adjuvant Endocrine Therapy in Patients with Ductal Carcinoma In Situ: A Population-Based Retrospective Analysis from 2005 to 2012 in the National Cancer Data Base. Ann Surg Oncol. 2015;22(10):3264-3272.

40. Nguyen TT, Hoskin TL, Day CN, Habermann EB, Goetz MP, Boughey JC. Factors Influencing Use of Hormone Therapy for Ductal Carcinoma In Situ: A National Cancer Database Study. Ann Surg Oncol. 2017;24(10): 2989-2998.

41. Taylor C, Correa C, Duane FK, Aznar MC, Anderson SJ, Bergh J, et al. Estimating the Risks of Breast Cancer Radiotherapy: Evidence From Modern Radiation Doses to the Lungs and Heart and From Previous Randomized Trials. J Clin Oncol. 2017;35(15):1641-1649.

42. Grantzau T, Mellemkjaer L, Overgaard J. Second primary cancers after adjuvant radiotherapy in early breast cancer patients: a national population based study under the Danish Breast Cancer Cooperative Group (DBCG). Radiother Oncol. 2013;106(1):42-49.

43. Ganz PA, Cecchini RS, Julian TB, Margolese RG, Costantino JP, Vallow LA, et al. Patient-reported outcomes with anastrozole versus tamoxifen for postmenopausal patients with ductal carcinoma in situ treated with lumpectomy plus radiotherapy (NSABP B-35): a randomised, double-blind, phase 3 clinical trial. Lancet. 2016;387(10021):857-65. Epub 2015 Dec 11.

44. Collins LC, Achacoso N, Haque R, Nekhlyudov L, Quesenberry Jr CP, Schnitt, et al. Risk Prediction for Local Breast Cancer Recurrence Among Women with DCIS Treated in a Community Practice: A Nested, Case-Control Study. Ann Surg Oncol. 2015;22 Suppl 3:S502-8.

45. Sweldens C, Peeters S, van Limbergen E, Janssen H, Laenen A, Patil S, et al. Local relapse after breast-conserving therapy for ductal carcinoma in situ: a European single-center experience and external validation of the Memorial Sloan-Kettering Cancer Center DCIS nomogram. Cancer J. 2014; 20(1):1-7.

46. Wang F, Li H, Tan PH, Chua ET, Yeo RMC, Lim FLWT, et al. Validation of a 
nomogram in the prediction of local recurrence risks after conserving surgery for Asian women with ductal carcinoma in situ of the breast. Clin Oncol (R Coll Radiol). 2014;26(11):684-91.

47. Yi M, Meric-Bernstam F, Kuerer HM, Mittendorf EA, Bedrosian I, Lucci A, et al. Evaluation of a breast cancer nomogram for predicting risk of ipsilateral breast tumor recurrences in patients with ductal carcinoma in situ after local excision. J Clin Oncol. 2012;30(6):600-7.

48. Burstein HJ, Polyak K, Wong JS, Lester SC, Kaelin CM. Ductal carcinoma in situ of the breast. N Engl J Med. 2004;350(14):1430-1441.

49. Wong JS, Chen YH, Gadd MA, Gelman R, Lester SC, Schnitt SJ, et al. Eight-year update of a prospective study of wide excision alone for small low- or intermediate-grade ductal carcinoma in situ (DCIS). Breast Cancer Res Treat. 2014;143(2):343-50.

50. Solin LJ, Gray R, Hughes LL, Wood WC, Lowen MA, Badve SS, et al. Surgical Excision Without Radiation for Ductal Carcinoma in Situ of the Breast: 12-Year Results From the ECOG-ACRIN E5194 Study. J Clin Oncol. 2015;33(33):3938-44

51. McCormick B. Randomized trial evaluating radiation following surgical excision for "good risk" DCIS: 12-year report from NRG/RTOG 9804. American Society for Radiation Oncology Annual Meeting, San Antonio, TX, October 21-24, 2018.

52. Rakovitch E, Nofech-Mozes S, Hanna W, Baehner FL, Saskin R, Butler SM, et al. A population-based validation study of the DCIS Score predicting recurrence risk in individuals treated by breast-conserving surgery alone. Breast Cancer Res Treat. 2015;152(2):389-98.

53. Rakovitch E, Nofech-Mozes S, Hanna W, Sutradhar R, Baehner FL, Miller $\mathrm{DP}$, et al. Multigene Expression Assay and Benefit of Radiotherapy After Breast Conservation in Ductal Carcinoma in Situ. J Natl Cancer Inst. 2017; 109(4):djw256.

54. Rakovitch E, Gray R, Baehner FL, Sutradhar R, Crager M, Gu S, et al. Refined estimates of local recurrence risks by DCIS score adjusting for clinicopathoIogical features: a combined analysis of ECOG-ACRIN E5194 and Ontario DCIS cohort studies. Breast Cancer Res Treat. 2018;169(2): 359-369.

55. Weinmann S, Leo MC, Francisco M, Jenkins CL, Barry T, Leesman G, et al. Validation of a Ductal Carcinoma In Situ Biomarker Profile for Risk of Recurrence after Breast-Conserving Surgery with and without Radiotherapy. Clin Cancer Res. 2020;26(15):4054-4063.

56. https://www.clinicaltrials.gov/ct2/show/NCT02766881. Evaluation of the DCIS Score for Decisions on Radiotherapy in Patients With Low/ Intermediate Risk DCIS (DUCHESS). Accessed 06.15.2021.

57. https://www.clinicaltrials.gov/ct2/show/NCT03448926. The PREDICT Registry for DCIS Patients With DCISionRT Testing (PREDICT).

58. Owen JR, Ashton A, Bliss JM, Homewood J, Harper C, Hanson J, et al. Effect of radiotherapy fraction size on tumour control in patients with early-stage breast cancer after local tumour excision: Iong-term results of a randomised trial. Lancet Oncol. 2006;7(6): 467-71.

59. Whelan TJ, Pignol JP, Levine MN, Julian JA, MacKenzie R, Parpia S, et al. Long-term results of hypofractionated radiation therapy for breast cancer. $\mathrm{N}$ Engl J Med. 2010;362(6):513-20.

60. Group ST, Bentzen SM, Agrawal RK, Aird EGA, Barrett JM, Barrett-Lee PJ, et al. The UK Standardisation of Breast Radiotherapy (START) Trial B of radiotherapy hypofractionation for treatment of early breast cancer: a randomised trial. Lancet. 2008;371(9618):1098-107.

61. Group ST, Bentzen SM, Agrawal RK, Aird EGA, Barrett JM, Barrett-Lee PJ, et al. The UK Standardisation of Breast Radiotherapy (START) Trial A of radiotherapy hypofractionation for treatment of early breast cancer: a randomised trial. Lancet Oncol. 2008;9(4):331-41.

62. King MT, Link EK, Whelan TJ, Olivotto IA, Kunkler I, Westenberg AH, et al.
Quality of life after breast-conserving therapy and adjuvant radiotherapy for non-low-risk ductal carcinoma in situ (BIG 3-07/TROG 07.01): 2-year results of a randomised, controlled, phase 3 trial. Lancet Oncol. 2020;21(5): 685-698.

63. Whelan TJ, Julian JA, Berrang TS, Kim DH, Germain I, Nichol AM, et al. External beam accelerated partial breast irradiation versus whole breast irradiation after breast conserving surgery in women with ductal carcinoma in situ and node-negative breast cancer (RAPID): a randomised controlled trial. Lancet. 2019;394(10215): 2165-2172.

64. National Comprehensive Cancer Network: NCCN Clinical Practice Guidelines in Oncology (Breast Cancer) Version 4.2021. Version 4.2021 April 28, 2021.

65. Eusebi V, Feudale E, Foschini MP, Micheli A, Conti A, Riva C, et al. Long-term follow-up of in situ carcinoma of the breast. Semin Diagn Pathol. 1994:11(3):223-35

66. Rosen PP, Braun DW, Jr., Kinne DE. The clinical significance of pre-invasive breast carcinoma. Cancer. 1980;46(4 Suppl):919-925.

67. Welch HG, Black WC. Using autopsy series to estimate the disease "reservoir" for ductal carcinoma in situ of the breast: how much more breast cancer can we find? Ann Intern Med. 1997;127(11):1023-1028.

68. Single-arm confirmatory trial of endocrine therapy alone for estrogen receptorpositive I-rdcisotbJ, LORETTA trial). https://upload.umin.ac.jp/cgi-openbin/ctr_e/ctr_view.cgi?recptno=R000032260. Accessed 06/12/2021.

69. Grimm LJ, Ryser MD, Partridge AH, Thompson AM, Thomas JS, Wesseling $J$, et al. Surgical Upstaging Rates for Vacuum Assisted Biopsy Proven DCIS: Implications for Active Surveillance Trials. Ann Surg Oncol. 2017;24(12): 3534-3540.

70. Patel GV, Van Sant EP, Taback B, Ha R. Patient Selection for Ductal Carcinoma In Situ Observation Trials: Are the Lesions Truly Low Risk? AJR Am J Roentgenol. 2018;211(3):712-713.

71. Oseni TO, Smith BL, Lehman CD, Vijapura CA, Pinnamaneni N, Bahl M. Do Eligibility Criteria for Ductal Carcinoma In Situ (DCIS) Active Surveillance Trials Identify Patients at Low Risk for Upgrade to Invasive Carcinoma? Ann Surg Oncol. 2020;27(11):4459-4465.

72. Muhsen S, Barrio AV, Miller M, Olcese C, Patil S, Morrow M, et al. Outcomes for Women with Minimal-Volume Ductal Carcinoma In Situ Completely Excised at Core Biopsy. Ann Surg Oncol. 2017;24(13):3888-3895.

73. Ganz PA. Quality-of-life issues in patients with ductal carcinoma in situ. J Natl Cancer Inst Monogr. 2010;2010(41):218-222.

74. Partridge A, Adloff K, Blood E, Dees EC, Kaelin C, Golshan M, et al. Risk perceptions and psychosocial outcomes of women with ductal carcinoma in situ: Iongitudinal results from a cohort study. J Natl Cancer Inst. 2008; 100(4):243-51.

75. Ruddy KJ, Meyer ME, Giobbie-Hurder A, Emmons KM, Weeks JC, Winer EP, et al. Long-term risk perceptions of women with ductal carcinoma in situ. Oncologist. 2013;18(4):362-8.

76. Katz SJ, Lantz PM, Janz NK, Fagerlin A, Schwartz K, Liu L, et al. Patterns and correlates of local therapy for women with ductal carcinoma-in-situ. J Clin Oncol. 2005;23(13):3001-7.

77. Morrow M, Winer E. De-Escalating Breast Cancer Surgery for Low-Risk Ductal Carcinoma in Situ-Reply. JAMA Oncol. 2020;6(7):1118.

78. Zhang B, Coopey SB, Gadd MA, Hughes KS, Chang DC, Oseni TO. Trends in Unilateral and Contralateral Prophylactic Mastectomy Use in Ductal Carcinoma In Situ of the Breast: Patterns and Predictors. Ann Surg Oncol. 2019;26(12):3863-3873

79. Byun DJ, Wu SP, Nagar H, Gerber NK. Ductal Carcinoma in Situ in Young Women: Increasing Rates of Mastectomy and Variability in Endocrine Therapy Use. Ann Surg Oncol. Epub 2021 Apr 29. 